\title{
Diurnal cycles in thermokarst lakes of a permafrost peatland
}

\author{
Shirokova L.S. ${ }^{1,2}$, Payandi-Rolland D. ${ }^{1}$, Lim A.G. ${ }^{3}$, Manasypov R.M. ${ }^{3}$, Allen J. ${ }^{4}$, \\ Rols J.-L. ${ }^{4}$, Bénézeth P. ${ }^{1}$, Karlsson J. ${ }^{5}$, Pokrovsky O.S. ${ }^{1}$ \\ ${ }^{1}$ Géosciences Environnement Toulouse, GET - CNRS - IRD - OMP - Université de Toulouse, 14, Avenue Edouard Belin, 31400 \\ Toulouse, France \\ ${ }^{2}$ N. Laverov Federal Center for Integrated Arctic Research of the Ural Branch of the Russian Academy of Sciences, 23, Naberezhnaya \\ Sev. Dviny, Arkhangelsk, Russia \\ ${ }^{3}$ BIO-GEO-CLIM Laboratory, Tomsk State University, 36 Lenina Pr., Tomsk, Russia \\ ${ }^{4}$ EcoLab, Université de Toulouse, CNRS, Toulouse, France \\ ${ }^{5}$ Climate Impacts Research Centre (CIRC), Umeå University, SE-901 87 Umeå, Sweden
}

\begin{abstract}
Despite the importance of surface waters of permafrost landscapes in carbon (C) emission, dissolved C, metal storage and export, the diel pattern of dissolved components and gases in thermokarst lakes remain virtually unknown. Here we discovered a factor of 2 to 3 higher $\mathrm{CO}_{2}$ concentrations and fluxes during the night compared to day-time in the high-DOC lake. The emission fluxes in the low-DOC lake increased from zero to negative values during the day to highly positive values during the end of the night and early morning. The bulk of dissolved $(<0.45 \mu \mathrm{m})$ hydrochemical parameters remained highly stable with $\pm 10 \%$ variation in concentration over 2 days of observation. Overall, the impact of diel cycle on dissolved $\mathrm{CH}_{4}, \mathrm{DOC}$, nutrient and metal concentration was below $10 \%$. However, neglecting night-time period may underestimate net $\mathrm{CO}_{2}$ emission by ca. 30 to $50 \%$ in small organicrich thaw ponds and switch the $\mathrm{CO}_{2}$ exchange from uptake/zero to net emission in larger thermokarst lakes. Given the dominance of large lakes in permafrost regions, the global underestimation of the emission flux may be quite high. As such, monitoring $\mathrm{CO}_{2}$ concentrations and fluxes in thermokarst lakes during months of extended night time (August to October) is mandatory for assessing the net emissions from lentic waters of frozen peatlands.
\end{abstract}

Keywords: GHG emission, thermokarst, pond, trace metal, organic carbon, warming

\section{Introduction}

The emission of greenhouse gases (GHG), particularly $\mathrm{CO}_{2}$ and $\mathrm{CH}_{4}$, from inland waters at high latitudes is a critical issue of these aquatic system behaviors under on-going climate warming (Serikova et al., 2019). The majority of dystrophic to mesotrophic aquatic systems in frozen peatlands drastically differ from oligotrophic northern rivers and lakes in the sense that the peatland thermokarst lakes and ponds are i) highly humic, and typically contain between 10 and $100 \mathrm{mg} \mathrm{L}^{-1}$ of DOC and ii) quite acidic, with $\mathrm{pH}$ ranging between 3.5 and 5.5 (Shirokova et al., 2019). The working hypotheses of this study is that the variability in external factors like temperature and light will exert primary control on DOC and related trace elements, and this will produce a diel cycle in $\mathrm{C}$ and elements concentrations and GHG emissions in thermokarst lakes. In order to test these hypotheses, we studied two thaw ponds with different size and DOM content and we quantified (1) the variation of dissolved $C$ and metal concentration between day and night and (2) the degree of diel variation in $\mathrm{CO}_{2}$ flux, in order to reveal the control of hydrochemical parameters by external factors such as temperature and light.

\section{Material and methods}

We studied typical thermokarst lake (Lake Trisino, $S_{\text {area }}=16920 \mathrm{~m}^{2} ; \mathrm{S}_{\text {watershed }}=0.108 \mathrm{~km}^{2}$, average depth $0.5 \mathrm{~m}$ ) and thaw pond (Chernoe, $\mathrm{S}_{\text {area }}=1830$ $\mathrm{m}^{2} ; \mathrm{S}_{\text {watershed }} \leq 500 \mathrm{~m}^{2}$, average depth $0.3 \mathrm{~m}$ ) located in the discontinuous permafrost zone of the Western Siberian Lowland (WSL). Observations were performed during $48 \mathrm{~h}$ on July $26-28^{\text {th }} 2018$, at stable anticyclone conditions without any precipitation event. Every 2 hours we measured the dissolved oxygen, specific conductivity, $\mathrm{pH}$, water temperature, partial pressure 
of $\mathrm{CO}_{2}\left(\mathrm{pCO}_{2}\right)$, dissolved $\mathrm{CH}_{4}, \mathrm{CO}_{2}$ fluxes $\left(\mathrm{FCO}_{2}\right)$, DOC, DIC, and dissolved major and trace elements, chloride, sulfide, fluoride and carboxylic organic ligands (lactate, acetate, propionate, formate, butyrate, pyruvate, galacturonate, glutarate, malate, tartrate, oxalate, phthalate, quinate, and citrate) and total microbial cell concentration.

\section{Results and Discussion}

The water temperature of the two lakes followed a similar diurnal cycle with a minimum temperature reached approximately $2 \mathrm{~h}$ after the sunrise. The concentration of DOC, phosphate, silica and carboxylate remained constant (formate, oxalate, pyruvate) or fluctuated without any diel pattern (acetate and lactate). The total cell number and biomass of bacteria, DIC, $\mathrm{Cl}, \mathrm{SO}_{4}^{2-}$, most major and trace elements did not exhibit any sizeable variations over the diurnal cycle as their concentrations remained stable (within \pm $10-15 \%$ ). The $\mathrm{pCO}_{2}$ demonstrated clear diurnal pattern with a factor of 2 to 4 times higher concentrations achieved at the end of the night and early morning compared with the middle of the day. The $\mathrm{FCO}_{2}$ was almost nil or negative during the day time in Trisino $\left(-0.02 \pm 0.02 \mathrm{~g} \mathrm{C} \mathrm{m}^{-2} \mathrm{~d}^{-1}\right)$, but positive in Chernoe $(0.12$ $\left.\pm 0.07 \mathrm{~g} \mathrm{C} \mathrm{m}^{-2} \mathrm{~d}^{-1}\right)$. During the night, the $\mathrm{FCO}_{2}$ strongly increased and became positive in Trisino $(0.12 \pm 0.1 \mathrm{~g}$ $\mathrm{C} \mathrm{m}^{-2} \mathrm{~d}^{-1}$ ), whereas in Chernoe, the night maximum was 2 to 5 times higher than the day minimum. Overall the impact of diel cycle on dissolved $\mathrm{CH}_{4}$, DOC, nutrient and metal concentration was below $10 \%$. However, neglecting night-time period may underestimate net $\mathrm{CO}_{2}$ emission by 30 to $50 \%$ in small organic-rich thaw ponds and switch the $\mathrm{CO}_{2}$ exchange from uptake/nil to a net emission in larger thermokarst lakes.

\section{Conclusion}

We observed stable pH, SUVA $_{254}$ and concentrations of DOC, dissolved $\mathrm{CH}_{4}$, nutrients, carboxylic acids, most major and trace elements in waters of acidic and humic thermokarst lake and thaw pond, during a continuous 2-days observation at generally anticyclone weather. In contrast, the $\mathrm{CO}_{2}$ concentration and emission exhibited clear diurnal pattern with a maximum after the sunrise (minimal surface water temperature) and a minimum during late afternoon day-time (maximum surface water temperature). It is possible that the balance between benthic respiration of dissolved and particulate organic matter and primary productivity of periphyton, aquatic macrophytes and submerged mosses was responsible for enhanced $\mathrm{CO}_{2}$ emission during the night and $\mathrm{CO}_{2}$ decrease or even uptake during the day. Neglecting night-time $\mathrm{CO}_{2}$ flux, especially in large thermokarst lakes, can sizably underestimate the region-upscaled global $\mathrm{C}$ emission. This result convinces the need to study diurnal variations in C emission of large (10-500 ha) thermokarst lakes as they mostly contribute to overall inland water surface of the region.

\section{Acknowledgments}

This work was supported by RSCF grants No. 19-77-00073 (30\%, sampling) and 18-77-10045 (20\%, data analysis), the Ministry of Education and Science of the Russian Federation no. 1.8195.2017/9.10, RFBR grants No 17-55-16008, No 19-05-50096, and No 20-05-00729, and RSF grant No 18-77-10045 for data analysis. The fieldwork was partially supported by the international program INTERACT for the 2018 campaign.

\section{References}

Shirokova L.S., Chupakov A.V., Zabelina S.A. et al. 2019. Humic surface waters of frozen peat bogs (permafrost zone) are highly resistant to bio- and photodegradation. Biogeosciences 16: 2511-2526. DOI: 10.5194/bg-16-2511-2019

Serikova S., Pokrovsky O., Laudon H. et al. 2019. High carbon emissions from thermokarst lakes of Western Siberia. Nature Communications 10: 1-7. DOI: 10.1038/ s41467-019-09592-1 